\title{
Analizando los textos de Historia, Geografía y Ciencias Sociales: La configuración multimodal de los pueblos originarios*
}

\author{
Analyzing the history, geography and social sciences textbooks: the multimodal configu- \\ ration of the native peoples
Analisando os textos de História, Geografia e Ciências Sociais: a configuração multi- modal dos povos nativos

\author{
Pamela Altamirano, Gerardo Godoy, Dominique Manghi, Gonzalo Soto ${ }^{a}$
}

aPontificia Universidad Católica de Valparaíso, Escuela de Pedagogía, Educación Diferencial. Telf.: 81207955. Correo electrónico: dmanghi@gmail.com

\begin{abstract}
RESUMEN
Dentro de la diversidad cultural chilena, los grupos étnicos identificados como pueblos originarios son considerados como una minoría desde la historia nacional, y son representados como tal en los textos escolares de Historia, Geografía y Ciencias Sociales distribuidos por el Ministerio de Educación. Esta investigación se centra en el análisis multimodal de un texto escolar de Historia con el propósito de conocer cómo configura el concepto de pueblos originarios a través de los diferentes recursos semióticos utilizados. Para esto se analiza los "Inicio de unidad" de Quinto Año básico. Los resultados indican que las imágenes de los textos presentan a los pueblos originarios como una voz ausente en la narración de su propia historia, siendo narrada desde la perspectiva de la voz del conquistador. Ante esto surge la necesidad de que los profesores se alfabeticen multimodalmente para dominar los diversos recursos semióticos y la naturalización de los significados construidos allí, para así mediar en la configuración de los pueblos originarios como parte de la diversidad cultural nacional.
\end{abstract}

Palabras clave: diversidad, pueblos originarios, multimodalidad, texto escolar.

\begin{abstract}
Among the cultural diversity of Chile, ethnic groups identified as native peoples are considered a minority from the point of view of national history, also they are presented as a minority on the history, geography, and social sciences textbooks provided by the Ministry of Education. The focus of this study is a multimodal analysis of a history textbook in order to show how the concept of native peoples builds up throughout the use of a variety of semiotic resources. To meet the former aim, there is an analysis of every 'unit opening' section present on a 5th grade textbook. The results show that the images of the texts introduce the native peoples as an absent voice in the narration of their own history, which is narrated from the perspective of the conqueror's voice. Under the light of the ideas above, it emerges a need for teachers to become multimodaly literate. In that way, they can manage the variety of semiotic resources and the naturalization of the meanings built there, in order to mediate in the configuration of the native peoples as part of the national cultural diversity.
\end{abstract}

Key words: diversity, native peoples, multimodality, textbook.

\section{RESUMO}

Dentro da diversidade cultural chilena, os grupos étnicos identificados como povos nativos são considerados como minoria desde a história nacional e são representados como tal em textos escolares de História, Geografia e Ciências Sociais, distribuídos pelo Ministério de Educação. A investigação centra-se na análise multimodal de um texto escolar de História e objetiva conhecer como se configura o conceito de povos nativos por meio dos diferentes recursos semióticos utilizados. Para tanto, analisa-se o "Início da Unidade" de quinto ano do Ensino Básico. Resultados indicam que

Esta Investigación corresponde a la extensión de una tesis de pregrado (Altamirano, Godoy, Mayorga y Soto, 2012) que se inserta dentro del Proyecto Fondecyt $N^{\circ} 11100169$. 
as imagens dos textos apresentam os referidos povos como uma voz ausente na narração de sua própria história, pois esta é contada desde a perspectiva do conquistador. Diante disso, surge a necessidade de que professores se alfabetizem multimodalmente para dominar os diversos recursos semióticos e a naturalização dos significados ali construídos para, assim, mediar a configuração dos povos nativos como parte da diversidade cultural nacional.

Palavras chave: diversidade, povos nativos, multimodalidade, texto escolar.

\section{INTRODUCCIÓN}

Desde la perspectiva de la educación inclusiva o educación para todos (Jomtiem, 1990), es fundamental considerar la diversidad cultural, debido a que nos otorga una mirada más amplia de los distintos actores que conforman nuestra sociedad. La diversidad abarca las creencias religiosas, condiciones físicas, emocionales, intelectuales, sociales, étnicas, entre otras (Alzate, Gómez y Romero, 1999). La diversidad cultural en nuestro país está representada por grupos que poseen menores oportunidades de expresión de opinión y de auto definición como grupo (Latour, 2008) entre ellos se encuentran los pueblos originarios. Cualquiera de estos grupos son representados en la historia del país de forma diversa, dependiendo de la posición desde la cual se los signifique, vale decir, desde la posición en que se narre su historia (Oteiza, 2011).

Así, la educación en la diversidad se refleja y concreta tanto a nivel macro o curricular, como también a nivel micro o de la relación entre profesor y estudiante, esto engloba dos pilares que se complementan: por un lado, la diversidad en tanto valoración de cada estudiante como un ser único; y por el otro, el reconocimiento de los grupos minoritarios en la sociedad, los cuales se escapan del estatus quo de la cultura en donde se suscitan, al tener visiones, formas de vida y necesidades distintas (Arnaiz, 2009).

En la expresión más concreta de esta relación de construcción de significados y de interacción con posturas y formas diversas de vivir, es importante remitirse a una de las herramientas semióticas mediadoras más tradicionales entre el conocimiento seleccionado en el currículo y la construcción que realiza el propio estudiante respecto de este saber. Este corresponde al texto o manual escolar el cual en nuestro país es distribuido desde el Ministerio de Educación a todas las escuelas chilenas que reciben subvención estatal.

Uno de los supuestos que orienta este estudio es que la manera de representar a los pueblos originarios en los textos escolares en los diferentes cursos de la trayectoria educativa, está teñida desde la perspectiva del narrador de la historia (Oteiza, 2006). La influencia de los textos escolares y las concepciones respecto de temas como los pueblos originarios en el proceso pedagógico, no es neutra y favorece una determinada mirada con la que los estudiantes aprenden a partir de estos materiales. Mirada que además correspondería a la política y postura ideológica que el Estado chileno quiere desarrollar en los escolares.

Por lo anteriormente expuesto, resulta importante indagar respecto a los pueblos originarios y cómo estos son presentados y construidos conceptualmente a partir de los textos escolares. Tales textos se presentan en una sociedad diversa y democrática; la cual - si desea avanzar hacia una sociedad inclusiva- debiera propiciar un pluralismo de visiones frente a la narración de la historia y de los participantes de la sociedad (Rüsen, 1992), para así construirse como participativa y diversa.

El objetivo de este estudio es dar cuenta de la configuración del concepto de pueblos originarios representada en los textos o manuales escolares, a la luz de lo expresado en el 
currículo nacional y en el compromiso con la educación para todos y todas: la formación de personas que valoran, conocen y reconocen a los pueblos originarios como parte de una diversidad que constituye la cultura de nuestro país (MINEDUC, 2004). Para lograr esto se analizan los textos escolares desde una perspectiva multimodal, en donde los significados son creados a partir de múltiples recursos entre ellos imágenes y escritura. A través de las unidades de significado se develan y representan los modos de vivir y de crear cultura sobre los pueblos originarios chilenos.

Así, la pregunta de este artículo será: ¿cómo se configura el concepto de pueblos originarios a través de los recursos semióticos dispuestos en los textos escolares? A continuación se presentan los fundamentos teóricos centrados en la conceptualización de los textos escolares y luego la perspectiva multimodal sobre la representación y comunicación. Después se sintetizan los aspectos metodológicos centrados esencialmente en el análisis de las imágenes en relación a la escritura mediante el análisis multimodal del discurso, para pasar a desarrollar los principales hallazgos de este estudio.

\section{MARCO TEÓRICO}

La cultura es una red comunitaria en donde es necesario que se escuchen todas las voces de la comunidad, por mas "pequeñas" que están puedan parecer (Geertz, 2003). Es en este sentido que las minorías tales como grupos ideológicos, sexuales, étnicos, etc. deberían tener una voz que narre su propio sentido y la relación de éste con las demás personas y cosas del mundo. Un caso particular de narración y construcción de sentido de una minoría, corresponde a los pueblos originarios. La narración es significada desde múltiples recursos, para esto es necesario definir el texto escolar como una herramienta para significar en contextos educativos y luego conocer la perspectiva multimodal para abordar la representación en los textos escolares.

\subsection{TEXTOS ESCOLARES Y PUEBLOS ORIGINARIOS}

Desde el enfoque sociohistórico, el lenguaje es un instrumento semiótico, es decir, una herramienta con la cual pensamos y configuramos una visión de mundo (Vigotsky, 1998; Wells, 2001). Vigotsky desarrolla esta idea a partir de una analogía con las herramientas de la vida cotidiana, percatándose cómo los instrumentos materiales poseían una función mediadora en las diversas actividades humanas (Wells, 2001). Así es como todos los instrumentos -todos los productos de un trabajo semiótico social que pasan a conformar una cultura (Kress, 2010)-, como el texto escolar por ejemplo, poseen una naturaleza dual: son al mismo tiempo materiales y semióticos, por lo cual, exigen de sus usuarios una actividad física e intelectual. La definición de semiosis para Vigotsky nos remite a la mediación de los procesos psicológicos superiores a través de los signos y los símbolos, no solo del lenguaje sino de cualquier recurso para la creación de significado. Es en este punto en que el enfoque sociohistórico se complementa con la semiótica social, definiendo el discurso como práctica social asociada a la semiosis.

La semiótica social plantea que el discurso de la historia y el discurso de su enseñanza son representaciones de los eventos históricos, más específicamente, son el resultado de aquello que se elige representar y aquello que queda sin ser representado. Estas opciones 
de representación son el reflejo de la interpretación ideológica de quien construye el discurso (Martin, 2006; Oteiza, 2006; Barletta y Mizuno, 2011), en el caso de los textos escolares, las editoriales.

Desde Martins (2006) el texto escolar se entiende como un artefacto cultural, el cual contiene un ensamblaje de recursos semióticos particulares dependiendo de la disciplina que se presente; la forma de abordar las matemáticas, la biología o la historia, se expresará de distinta manera, utilizando escritura, gráficos, fotografías, líneas de tiempo, etc. los cuales serán mediados por el docente. El texto escolar se constituye como un elemento mediador de las interacciones discursivas entre los diferentes sujetos que construyen conocimiento a cerca de historia en la escuela: autores, científicos, divulgadores, profesores y alumnos, articulando diferentes voces y horizontes sociales y conceptuales.

En el caso de los pueblos originarios como conocimiento o contenido curricular, es importante considerar la relación de los textos escolares con los acontecimientos actuales, o con la relación histórica que tienen estos con el Estado chileno, y con la ciudadanía en general. Estos instrumentos semióticos distribuidos ampliamente a lo largo de la población escolar chilena tienen influencia en el sentido por el cual quiénes somos educados tendemos a configurar de cierta forma nuestro conocimiento respecto de los pueblos originarios, a la diversas etnias y a las culturas que se consideran ajenas a la nuestra (Van Dijk, 2003). En relación a esto, existen variados estudios referidos a la temática en otros países. En Guatemala, por ejemplo, Wilhelm (1990) halló que el grupo étnico maya se encontraba ausente o minimizado en el material de enseñanza primaria. Alzate et al. (1999) descubrieron que las imágenes de los textos escolares colombianos reproducen una imagen estereotipada y discriminatoria de las mujeres. Calzadilla y Salazar (2000) expresan que los textos escolares sobre la historia de Venezuela atribuyen a los negros una posición marginal, fuera de la realidad contemporánea de la cultura nacional, sumado a que Tulio Ramírez (2002) destacó que tanto negros como indígenas aparecen con muy poca frecuencia y siempre en posición subyugadas en los textos que fueron revisados.

Así es como se pueden apreciar algunos atisbos de la problemática que acontece en la utilización de los textos escolares, sobre todo en la construcción conceptual de diferentes acontecimientos o culturas que se transmiten desde una ideología determinada; es este el caso de los pueblos originarios. Estos textos son muy importantes en la construcción de la identidad y la manera de representar a los propios habitantes con las características que se les asignan (Ilich, 2011). Pero, ¿cómo es que se construyen estos significados y representaciones conceptuales?

\subsection{MULTIMODALIDAD: SIGNIFICADOS, FUNCIONES Y CONTEXTO}

El concepto de multimodalidad (Kress y van Leeuwen, 1996), formulado desde la Semiótica Social (Halliday, 1978) explica la práctica semiótica dejando de lado la idea tradicional de que el principal y único código para comunicar es la lengua. Por el contrario, la teoría de la Semiótica Social sostiene que cada recurso utilizado para crear significado tiene un potencial diferente para la comunicación, el que está dado tanto por su materialidad como por las necesidades de los grupos sociales que han estabilizado su uso para lograr ciertas funciones.

La multimodalidad es definida, entonces, como el uso de diversos modos semióticos en el diseño de un producto o evento semiótico, junto con la forma particular en que 
estos modos son combinados -ellos pueden, por ejemplo, reforzarse uno a otro, cumplir roles complementarios o estar jerárquicamente ordenados (Kress, 1996). Un artefacto semiótico muy cercano y popular por su masificación institucionalizada es el texto o manual escolar. Este, a través de la tecnología mediante la cual es producido, presenta un ensamblaje de diversos modos o recursos para la configuración de sentidos (Kress, 2010). Así en un texto escolar las editoriales y diseñadores diseñan significado relacionando imágenes, textos escritos, símbolos, etc. para construir significados complejos, los que a su vez serán mediados por el profesor en el aula quien resalta tal o cual recurso y significado según el contexto y objetivo.

Considerando al hombre como un ser social, es que entendemos que la comunicación a través de diversos recursos comprende una decisiva influencia en la configuración de los modos y modas culturales, puesto que corren paralela a la impronta que ejercen en los hábitos y maneras de definir las pautas de interacción social, instaurándose en el consciente colectivo, modelando la manera en que cada uno entiende, interpreta y representa la realidad (Petrus, 1997).

Una de las formas cómo se puede representar la realidad es a través de las imágenes, en donde la actividad mental del hombre se dinamiza por el efecto del aprendizaje socio-cultural, en la medida en que se internalizan los componentes contextuales. Es por esto la importancia de los signos o símbolos que tienen significado definido socialmente; puesto que desde el contexto social se configuran e interiorizan los significados de las personas (Vigotsky, 1998). Así es como la teoría de la Semiótica Social afirma que todos los modos o recursos semióticos utilizados por los seres humanos para crear significado cumplen dos funciones esenciales (Halliday, 1978): una para la representación y la otra para la comunicación (Kress, 2010).

La primera función representativa o metafunción ideacional, supone que la totalidad de la experiencia humana sería potencialmente posible de ser convertida en significado. Por lo tanto, el habla, las fotografías, los dibujos, la escritura, entre otros modos o recursos constituirían sistemas de significados que ofrecen una teoría de la experiencia humana. El significado ideacional tiene que ver con la representación de quién hace qué, a quién, cuándo, dónde, por qué y cómo; reflejada cuando utilizamos algún recurso semiótico para representar nuestras experiencias acerca del mundo, para describir eventos, etc. (Eggins y Martin, 2003; Oteiza, 2006). La segunda función, la comunicativa o metafunción interpersonal, enactúa las relaciones sociales y personales con las otras personas del entorno, donde se organiza la realidad social de las personas con las cuales interactuamos. A partir del uso de los diversos recursos semióticos disponibles para el intercambio de significados se llevan a cabo diversas acciones comunicativas: afirmaciones, preguntas, órdenes; expresando cuán seguros nos sentimos de lo que decimos, diciendo lo que sentimos respecto a las cosas, cómo valoramos a las personas y sus actos, etc.; efectuado en la creación de significado o semiosis (Oteiza, 2006; Moss, 2010).

Uno de los recursos semióticos que serán analizados, son los recursos visuales o imágenes que se presentan en los textos escolares, a partir de la metafunción ideacional e interpersonal, observando qué idea busca construir la imagen y qué información entrega o solicita a los lectores.

A partir de la teoría de la Semiótica Social, Kress y van Leuween (1996) han desarrollado la gramática visual donde se consideran una serie de elementos que participan de forma interactiva para crear significados ideacionales e interpersonales de manera 
visual y que son importantes a tener en cuenta en la exploración e interpretación de elementos gráficos.

En la gramática visual la función ideacional se realiza a través de dos tipos de representación: la narrativa y la conceptual. La narración visual muestra dos objetos o personas que pueden mostrarse vinculados por un proceso de interacción en el cual uno de ellos realiza una acción que recae sobre el otro. Mientras que la conceptualización visual tiene que ver con representaciones estáticas, sin personas en interacción. Las conceptualizaciones visuales puedes ser analíticas en aquellas representaciones que describen objetos en términos de las partes que los componen; pueden ser clasificatorias cuando los objetos pueden ser representados como elementos integrantes de una clasificación, o pueden ser simbólicas cuando las imágenes apuntan a qué significan, o qué son los participantes (Kress y van Leeuwen, 1996).

En cuanto a la gramática visual para la comunicación de la metafunción interpersonal, esta se realiza a partir las interpretaciones sociales respecto de los significados, y que en esta propuesta se representa a través de cinco formas visuales de establecer las relaciones: 1) Contacto; 2) Distancia social; 3) Perspectiva; 4) Modalización y 5) Vector.

En relación al Contacto este aspecto se refiere a la relación entre el personaje representado y el lector de la imagen; esta puede aludir a una petición o demanda (personaje de frente al lector lo involucra estableciendo contacto visual y le solicita información); o a una oferta de información (personaje en posición diagonal o lateral solo entrega información al observador). En cuanto a la Distancia Social, o cuán próxima se establece la relación interpersonal, esta puede ser de intimidad (representación muy cercana o en primer plano), relación social (distancia media) y relación impersonal (personajes representados en la lejanía). La Perspectiva tiene que ver cómo representamos las relaciones de poder de manera visual; estas pueden ser frontal (personaje a la misma altura del lector, simetría de poder), oblicua (personaje levemente más arriba o abajo que el punto de vista del lector, diferencia de poder) o vertical (ya sea el lector o el personaje en la posición alta observando desde la altura al otro, uno en relación de poder sobre el otro). La Modalización tiene que ver con el grado de veracidad y a quien es atribuida la responsabilidad de la representación. El autor del ensamblaje multimodal puede optar por una representación naturalística (fotos o pinturas que apelan a "lo real"), una representación científica (mapas, gráficos, líneas de tiempo, dando veracidad a lo representado atribuyendo la autoría a la ciencia) y una representación abstracta o sensorial (en la cual se da cuenta de una postura personal). El Vector es lo que dinamiza el espacio visual de una imagen, siendo la línea de energía o contacto que atraviesa una imagen. Existen dos tipos de vectores: 1) la línea de mirada del espectador o camino de lectura y 2) las líneas de fuerza representadas en el espacio (miradas, acciones, movimientos de figuras representadas o de fuerzas naturales). Los autores Painter, Martin y Unsworth (2012) han ampliado estas herramientas no solo a la relación entre los personajes y los lectores, sino también entre los propios personajes representados visualmente.

Teniendo en cuenta estas definiciones que aportarán al análisis posterior de los sentidos que busca construir el texto escolar, se revisarán de forma sistémica como interactúan todos estos recursos de manera multimodal para configurar el concepto de pueblos originarios. 


\section{METODOLOGÍA}

Esta investigación es parte de un proyecto mayor el cual aborda la enseñanza de la historia y de la biología escolar desde la perspectiva multimodal (Proyecto Fondecyt 11100169). Dentro de los objetivos planteados, este artículo apunta a la descripción de los recursos semióticos utilizados en los textos escolares y su potencial para la representación con fines educativos.

El enfoque teórico metodológico corresponde a la Semiótica Social (Kress y van Leeuwen, 1996), la cual propone que se crean significados a partir de los recursos semióticos disponibles en la cultura, en un dinamismo entre lo que reflejan -como parte de los significados estabilizados e institucionalizados- y a la vez construyen las comunidades en cada nuevo acto de creación de sus significados. El diseño metodológico corresponde a un estudio documental el cual investiga en un texto escolar como un documento de acceso público. El análisis del documento en cuestión se lleva a cabo desde el Análisis Multimodal del Discurso (Kress, 1996). Las herramientas heurísticas utilizadas para explorar los textos multimodales incluyen: las nociones de macrogénero y género curricular, las metafunciones hallidayanas, las nociones de medio semiótico (interacción cara a cara, impresos y electrónicos), modo o recurso semiótico (lengua oral o habla -en este estudio no se profundiza en la prosodiagestos, dibujos, fotos, escritura, etc.) y la gramática visual (Kress y van Leeuwen, 1996).

Tal como se indicó anteriormente, de la totalidad del corpus de textos escolares de historia relacionados con el tema de pueblos originarios, en este artículo se abordará el curso que desarrolla de manera más extensa el tema, tanto porque se encuentra indicado así en planes y programas curriculares, como porque la editorial ha optado por ocupar más páginas en su desarrollo: $5^{\circ}$ año de Educación Básica. Dada la profundidad del análisis se presentan los hallazgos en función de las introducciones a todas las unidades de este texto que desarrollan el tema central del estudio: los pueblos originarios.

El texto escolar ha sido descargado a través de la sección de "textos escolares" de la página virtual del Ministerio de Educación durante el año 2011.

Figura 1. Funciones de la Educación Física Escolar. Fuente: Díaz Lucea (1994)

\begin{tabular}{|c|c|c|c|c|}
\hline Curso & Nombre & Editorial & Año & Autores \\
\hline 5to Básico & $\begin{array}{l}\text { Historia, geografía } \\
\text { y ciencias sociales. }\end{array}$ & $\begin{array}{l}\text { MN editorial } \\
\text { limitada. }\end{array}$ & 2009 & $\begin{array}{l}\text { Victoria Silva Villalobos y } \\
\text { Fernando Ramírez Morales }\end{array}$ \\
\hline \multicolumn{5}{|c|}{$\begin{array}{l}\text { Unidad 2: La población americana: características y desafíos (34-36) } \\
\text { Unidad 4: La conquista española de América (90-106) } \\
\text { Unidad 5: La Conquista de Chile (116-128) } \\
\text { Unidad 6: La sociedad colonial americana (136-149) } \\
\text { Unidad 7: Chile colonial (158-164) }\end{array}$} \\
\hline \multicolumn{5}{|c|}{ Planes y Programas de $5^{\circ}$ Básico : Objetivos Fundamentales Verticales } \\
\hline \multicolumn{5}{|c|}{$\begin{array}{l}\text { Comprender que el territorio americano se encontraba poblado por una diversidad de } \\
\text { pueblos al momento de la conquista y caracterizar sus principales civilizaciones. } \\
\text {-Describir los rasgos fundamentales del proceso de conquista de América y del actual } \\
\text { territorio chileno, y comprender que la resistencia mapuche constituye una de las } \\
\text { particularidades del proceso de conquista de Chile }\end{array}$} \\
\hline
\end{tabular}




\section{HACER EXPLÍCITO LO IMPLÍCITO: INTERPRETANDO LAS IMÁGENES DE LOS TEXTOS ESCOLARES DESDE UNA PERSPECTIVA MULTIMODAL}

En este apartado se desarrollan los análisis de las introducciones de las unidades 2, $4,5,6,7$, tomando en cuenta los insumos teóricos presentados previamente, en busca de la interpretación de la configuración del concepto de pueblos originarios en $5^{\circ}$ año básico desde una perspectiva multimodal.

Imagen 1. 5to básico p.34, MN Editorial Limitada (2009), Introducción a Unidad 2.

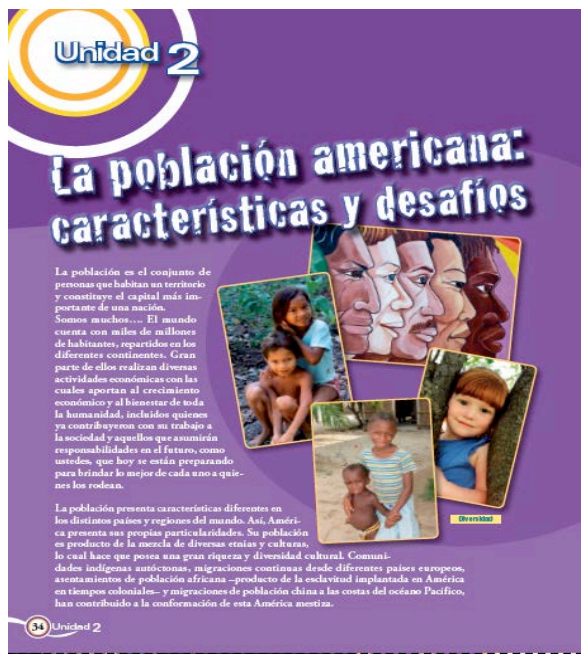

La Unidad 2 de 5to año básico lleva por título "La población americana: características y desafíos". Para caracterizar a la población americana, se presenta como introducción un ensamblaje semiótico construido a partir de imágenes conceptuales simbólicas y escritura, en donde se construye la idea de una América Diversa a partir del segundo párrafo escrito que indica la diversidad de etnias y culturas -en el cual los pueblos originarios quedan enumerados junto con los inmigrantes tanto europeos como chinos, y la población llegada de África-. Junto con la escritura las imágenes aportan significados referidos a la variedad de rasgos étnicos representados tanto en las fotografías como dibujo. Destaca el dibujo el cual es el único de carácter abstracto, plasmando una pintura de estilo mural que indica que la representación no ha sido realizada por la editorial sino por artistas americanos, representando la misma clasificación de etnias que el párrafo escrito. Esta representación es la única que se presenta en una perspectiva oblicua ofreciendo información al lector. El resto de las imágenes en su conjunto expresan el mismo sentido, la construcción de lo diverso, pero al representar el contacto ocular con el lector de manera directa buscando vinculación, lo diferente pasa a ser ese otro que no es igual a nosotros -los lectores-, los diferentes son "ellos" -los representados-.

Este sentido de exclusión se logra principalmente a través de las imágenes naturalísticas que expresan a diversas etnias como una realidad existente, representadas por fotografías de niños en ambientes de la naturaleza, niños representados que se dirigen a 
niños lectores y una diversidad de lo originario, como si lo diferente, fuera justamente lo originario. La idea de una América diversa se construye en base a una oposición diferente-normal, lo normal es la voz del narrador, la mezcla de etnias, mientras que por oposición lo diverso es la etnia pura, entre ellas la indígena: la cultura originaria. La distancia de intimidad también potencia este sentido, todas las imágenes son cercanas, se aprecia el detalle del rostro, la expresión de los ojos, parece otorgarse una valoración de lo distinto, exacerbando al otro como diverso, como minoría, mientras que hay un observador silencioso que se mantiene en lo común, lo normal, lo que no es diferente.

¿Se sentirá identificado un estudiante perteneciente a los pueblos originarios al ver estas imágenes? En términos generales, el diálogo que se muestra entre las imágenes analizadas en esta introducción de unidad, apunta principalmente a la configuración de un concepto de lo diverso, pero no se aclara ¿Quiénes miran esta diversidad? Si nos posicionamos en esta pregunta, lo diverso es exclusión para el niño perteneciente a un pueblo originario, pues se le muestra su cultura o etnia, desde la representación de otro, la cual está narrada desde una perspectiva de lo diferente. En definitiva, lo que se muestra en esta introducción del texto escolar asume que el lector es parte de la mezcla étnica, sin dar la posibilidad a que sea parte de uno de los pueblos originarios. La representación habla de una América Diversa que corresponde a otros, no a lo que algunos estudiantes pueden vivir, pues queda excluido de lo que su cultura narra como diverso.

Un aspecto interesante que se comunica con las imágenes al interaccionar con el primer párrafo escrito en donde se valoriza la diversidad de manera secundaria, y donde surge como principal virtud valórica, la participación en el desarrollo económico global, invitando explícitamente a los niños a participar en este desarrollo económico, expresando que de hacerlo se le hace un bien a la humanidad y definiendo la diversidad como parte del capital de América. La pregunta que se sigue de este texto es: ¿las imágenes, apoyan este texto? ¿Qué actividad económica realizan los niños de las imágenes? Lo que queremos decir en este ámbito, es que las imágenes sugieren un habitar diverso, pero el texto plantea una forma de vida valorada como correcta, en donde lo correcto y bueno es aportar en el desarrollo económico por el bienestar de la humanidad. Cabe preguntarse por el espacio para los valores propios de los pueblos originarios: ¿los pueblos originarios tienen como fundamento de vida esta consigna? De esta manera, se le presenta al escolar de $5^{\circ}$ año básico que si el indígena -así como aquellos que "somos" producto de una mezcla étnica- cumple con esta premisa de desarrollo, cabe dentro del espacio de aquello que se acepta, cuando deja su cultura ancestral y se suma a una cultura capitalista. 


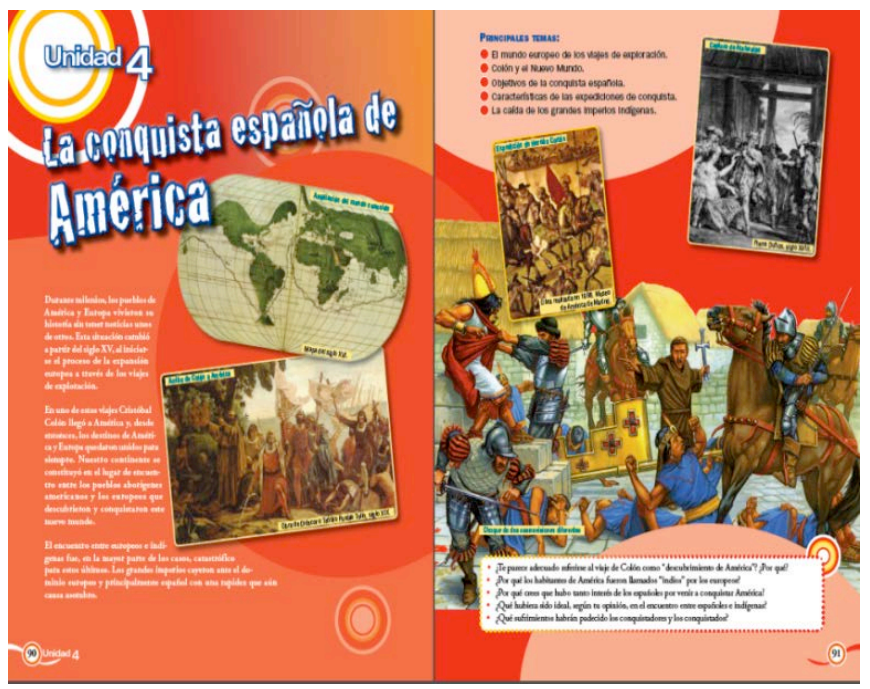

La Unidad 4 lleva por nombre "La conquista española de América"; la palabra conquista corresponde a una metáfora gramatical que oculta el proceso tras este concepto: alguien conquista algo o a alguien. En este aspecto se aprecia que los pueblos originarios pasan a constituirse en la categoría de lo conquistado: es el inicio de la conceptualización de una dialéctica conquistador-conquistado.

¿Cómo se expresa visualmente esta conquista española? En cuanto a los significados ideacionales o la representación de la experiencia, es posible observar la relación de las imágenes en el texto, en donde todas potencian de forma coherente el desarrollo de la idea de conquista de los pueblos originarios. Cada imagen representa un ámbito particular de información: lo científico, lo político, lo religioso y lo militar. Las imágenes expresan la justificación de la conquista en estos cuatro ámbitos.

Primero existe la presencia de un mapa, en que se muestra la ruta como la visión del europeo con respecto a las Américas. Se presenta como un fundamento científico técnico del cómo llegaron los españoles hasta América en una imagen conceptual de tipo analítico que se esfuerza en segmentar el mundo. El mapa potencia el sentido del resto de las imágenes, mediando como iniciador de la narración conjunta de todas las imágenes en un recorrido de lectura de la página de izquierda a derecha, representándose como un argumento "válido" para la conquista.

En segundo lugar, aparece el poder religioso, expresado en la aparición de un monje franciscano que sostiene una cruz con vehemencia interactuando en un ataque de carácter militar. La distancia social en la cual se presenta la imagen permite ver los detalles de la misma, por ejemplo, el rostro iracundo del monje y el rostro de sufrimiento de los personajes representados como aborígenes. Este monje se posiciona en el centro de la imagen, es decir, es uno de los personajes principales en la composición de la totalidad de la imagen, y es justamente el personaje que articula el poder religioso y militar, contemplando de forma oblicua y vertical a los aborígenes en una clara postura de autoridad. 
En tercer lugar, en relación a la fuerza física y militar, se observa el ataque de los españoles, en donde todos observan de manera vertical a sus adversarios representando el poder sobre el otro. En todas las imágenes son los españoles los que someten y los aborígenes son los sometidos por fuerza; una imagen que caracteriza esto es la de Atahualpa desmayado frente al español que le apunta con el dedo.

En cuarto lugar, políticamente, se observa la aparición de Cristóbal Colón en representación de la monarquía española, conquista en su nombre, se arrodilla frente a ella, se aborda la conquista de manera romántica, gloriosa, heroica. En esta imagen persiste la visión vertical, en donde todos los personajes contemplan a Colón, mientras Colón contempla al cielo apelando a una verticalidad superior (¿Dios?).

Junto a estos significados, las pinturas de diferentes periodos históricos funcionan agregando veracidad, como fuentes primarias y secundarias de una voz externa que nos relata la conquista. Los recursos utilizados, tales como cuadros y mapas, son de origen europeo mientras que la narración más crítica aparecida en el conjunto de imágenes, corresponde a una caricatura altamente violenta, en donde se expresa de forma abstracta un acontecimiento que se puede considerar o no como real. A diferencia de esta representación, el caso de las pinturas se expresa a modo naturalístico, lo que le otorga un rigor diferente: el rigor de lo documentado como real. En general, se aprecia una configuración del concepto de lo conquistado, en donde existe una sola narración del acontecimiento, la narración del europeo que se aprecia como conquistador dejando de lado las otras posibles narraciones e interpretaciones. En ningún momento se da espacio para la voz de los pueblos originarios para autodefinirse y narrar la conquista desde su perspectiva. La idea construida, referente a los pueblos originarios, es una conquista justificada por el poder científico, político, militar y religioso de los españoles. El recurso escritura representa el concepto "la conquista" como título, al corresponder a una metáfora gramatical limita la posibilidad diálogo o discusión con respecto a qué y cómo sucedieron los acontecimientos (Halliday \& Martin, 1997) en los tiempos de la aparición española.

Imagen 3. 5to básico pp.116 y 117. MN Editorial Limitada (2009)

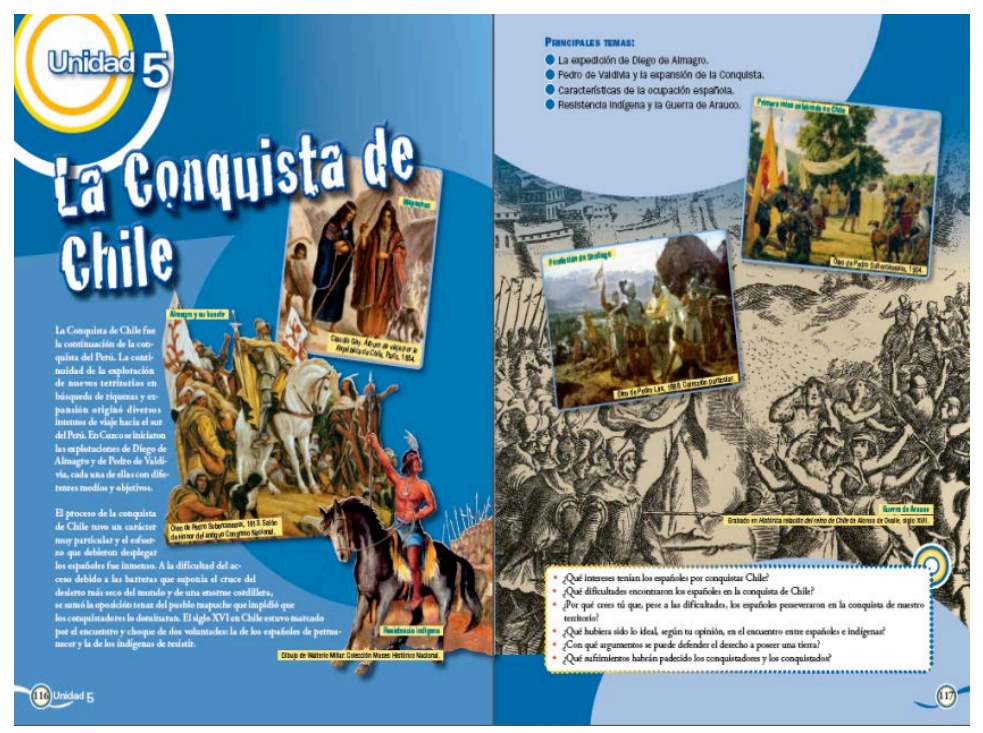


El inicio de la Unidad 5 lleva por nombre "La conquista de Chile", en ella se expresa la misma construcción ideacional que en la Unidad 4 referida a la conquista americana; se representa tanto mediante la escritura como mediante las imágenes el poder político, religioso y militar, pero esta vez en tierras chilenas.

Lo político es representado en la fundación de Santiago, en donde se presenta a un Diego de Almagro empoderado, desde una perspectiva vertical y oblicua, lo que evidencia una relación de poder frente a lo que observa, en este caso Santiago. Cabe mencionar que esta fundación es expresada de forma simbólica a través de una caricatura ubicada al centro de la página 116 donde resalta la figura de Diego de Almagro, el cual aparece sobre su hueste de españoles y algunos indígenas, y por sobre lo que sería Santiago, sosteniendo una espada por su filo en una actitud imponente. Es Almagro el que posee el protagonismo, el actor principal en la composición de la imagen, en donde el vector de todas las miradas apunta hacia su persona; lo cual no deja de ser interesante teniendo en cuenta que esta imagen corresponde a una caricatura realizada por un dibujante contemporáneo, lo cual expresa la visión actual de un Diego de Almagro.

Este grupo de imágenes resulta particular ya que se representa la presencia de pueblos originarios, en este caso mapuches; la particularidad radica en que la presencia mapuche es neutra, no hay una acción concreta en su narración y se presenta de forma aislada, lo que evoca más bien un uso simbólico de los personajes.

La narración visual presentada en lo político, religioso y militar se expresa en la fundación de Santiago, la primera misa realizada en Santiago y un ataque español a un grupo de mapuches, en donde se aprecia lo militar y lo religioso articulado en una sola imagen. Todas estas imágenes se relacionan ideacionalmente en una gran narración que expresa la acción de los españoles sobre los mapuches; una acción de poder, lo cual sigue la línea de las imágenes previamente analizadas. Desde lo interpersonal se aprecia una perspectiva oblicua y vertical en donde los españoles son quienes expresan una relación

Imagen 4. 5to básico pp.136 y 137. MN Editorial Limitada (2009)

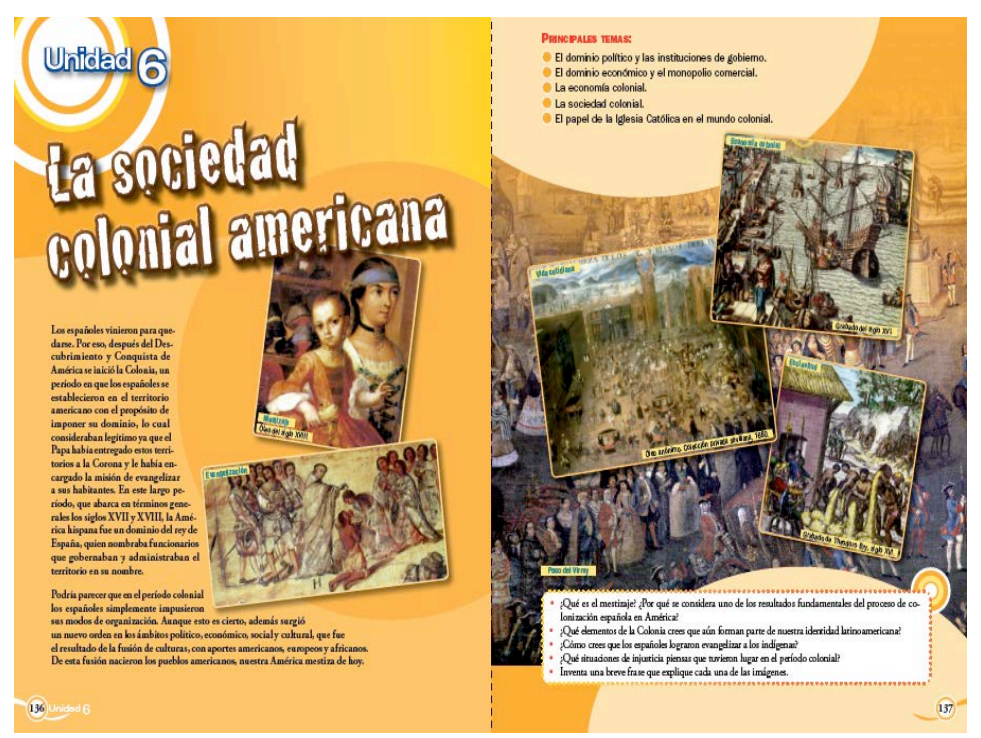


de poder, al estar siempre por sobre el mapuche que se ve sometido o atacado ya sea de forma física o simbólica (a través de lo religioso). Los recursos utilizados corresponden principalmente al tipo naturalístico, potenciado este sentido de expresar de forma fidedigna y real el acontecimiento narrado través de la voz de otros, a pesar de ser citadas como obras muy posteriores al acontecimiento mencionado (fuentes secundarias). El contacto, en general, corresponde a una oferta, es decir, nos ofrece información de que hay una conquista en donde el español es el protagonista y que realiza esta acción sin ser cuestionado, sin dar la opción de involucrarse con los personajes representados.

La Unidad 6 lleva por nombre "La sociedad colonial americana" en el conjunto de imágenes se aprecia cómo vivían en América Latina durante la colonia europea, lo cual se expresa de la siguiente manera. Desde una perspectiva ideacional, las imágenes representan narraciones visuales en donde los personajes ejecutan acciones o conductas fácilmente observables; se construye la idea de lo colonial, la vida religiosa evangelizadora, la vida económica, y la vida social. En estas acciones se representan a los pueblos originarios de manera esclavizada al servicio del colono europeo, o evangelizada y transformada. El mestizaje se expresa en una pintura con personajes de rasgos europeos y vestidos como tales, lo cual expresa la monopolización del discurso colonial, se expresa y resalta el rasgo europeo dentro de lo mestizo, no hay presencia indígena en este respecto. Sumado a esto se aprecian imágenes de la vida económica en los puertos Americanos: grandes barcos atiborrados de insumos mercantiles, lo cual aporta una imagen de crecimiento económico. La vida social se expresa en la lejanía, la distancia social no permite observar lo cotidiano del hacer diario, no se ven los rasgos del ciudadano, ni se aprecia si son aborígenes, mestizos o europeos. Se representa una ciudad atiborrada de personas inidentificables, lo que se traduce en una ciudad cuya identidad tiene que ver con las actividades de la ciudad y, a partir de las imágenes que rodean a la ciudad, lo representado parece ser un grupo de españoles que viven en una ciudad americana.

En tanto a lo religioso, se construye la idea de sumisión espiritual por parte de los aborígenes. Los personajes que aparecen en la imagen, se bautizan sin oponer resistencia, son evangelizados por la paz. Las dos imágenes donde aparecen pueblos originarios corresponden, por una parte, al personaje esclavizado sirviéndole al hombre europeo y, por otra, al personaje sumido al nuevo dios por aparente decisión propia. La participación de un indígena corresponde a un evangelizado o a un esclavo, lo cual crea la idea de ser las únicas dos opciones de estos en la cultura colonial. En este sentido, se aprecia claramente que el hablante es siempre el europeo, mientras que la voz del indígena y de los pueblos originarios no es representada como actor en ningún momento, solamente aparece su presencia como meta o beneficiario en las relaciones semánticas visuales.

Desde lo interpersonal las imágenes presentan un contacto de oferta, entregando información de la historia que relatan. La perspectiva es oblicua, lo cual no permite una cercanía con el interlocutor; esto se potencia aún más con la distancia social media e impersonal, con las cuales se muestra una suerte de indiferencia en relación al interlocutor que observa, se le resta importancia a estos mensajes esclavizantes de los pueblos originarios y se potencia el desarrollo económico y urbano de lo europeo.

En conclusión, en la Unidad 6 nuevamente se aprecia una relación de poder por parte del europeo por sobre el indígena, una suerte de paternalismo en donde se evangeliza para salvarle, y se le esclaviza para culturizarlo mediante el trabajo. El hablante es el español, se hegemoniza la postura europea y la palabra del indígena queda muda frente a este acto. 


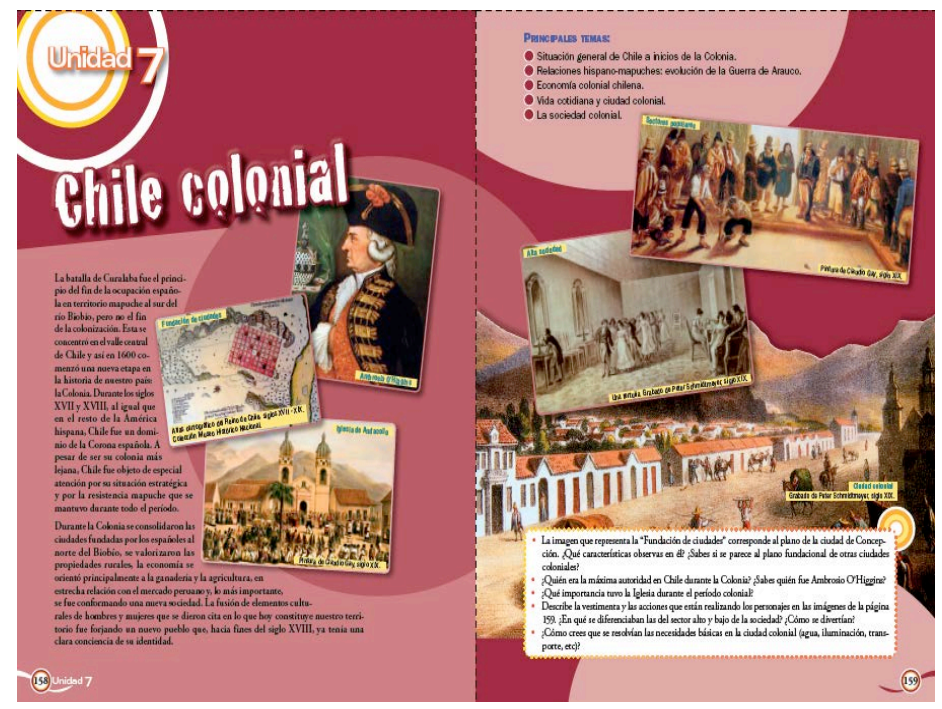

La Unidad 7 se titula "Chile colonial" y se intenta representar la vida en Chile durante la colonia. Se aprecian distintas imágenes que representan esta vida, además del retrato de un personaje considerado como relevante para este efecto.

Desde lo ideacional se presenta el periodo histórico de la colonia en donde se muestran actividades religiosas y de diversión, junto con la ciudad típica colonial en Chile. Existe una imagen conceptual analítica correspondiente a un mapa de ciudad, el cual le entrega al conjunto de imágenes un rigor científico. Se construye la idea de que el europeo con su técnica desarrolla las ciudades como las conocemos. Esto se potencia con las imágenes en donde se presentan las actividades de carácter cultural en las ciudades coloniales. Nuevamente aparece la presencia de la iglesia y la presencia política a través del retrato de Ambrosio O'Higgins. Destaca la total ausencia de pueblos originarios en todas las imágenes del inicio de unidad, parece ser que no hay aporte cultural, espiritual o político por parte de los pueblos originarios.

En tanto a los significados interpersonales se aprecia un contacto de oferta, en donde nos muestran los diversos logros de los europeos en América (logros desde la perspectiva europea), sumado a esto las imágenes se presentan en distancia social e impersonal, lo que otorga una visión magnánima de los desarrollos europeos, grandes ciudades, templos, etc. Nuevamente, no se permite distinguir rasgos físicos o características individuales de los personajes de ciudad; solo el retrato de Ambrosio O’Higgins se muestra de manera cercana, con detalles, lo cual le otorga un rol especial en el conjunto de imágenes, se hace protagonista en este diálogo de imágenes.

Todas las imágenes corresponden a fuentes pictóricas que se presentan de forma naturalística, dándole un valor de lo real, como exponiendo de forma fidedigna lo que ocurría en la época colonial.

En general, en la Unidad 7 los significados representados de manera visual muestran a la Colonia como la España americana, en donde se crean grupos sociales que se divierten 
y viven de diferente forma, se banaliza la Colonia a un acontecimiento de divertimento, se dejan de lado situaciones de importancia histórica y social para otros participantes del periodo histórico de aquello que se llama la Colonia.

\section{CONCLUSIONES}

El análisis multimodal del discurso permite describir la importancia de las imágenes en la configuración de la noción de pueblos originarios en el texto escolar de $5^{\circ}$ Año Básico, distribuido por el MINEDUC. Las imágenes junto con la escritura en las introducciones de unidad revisadas potencian el sentido de ausencia de lo originario, se perpetúa una sola voz histórica, la española, dejando de lado la perspectiva de los pueblos originarios.

La representación más común corresponde a un pueblo sometido y mudo frente a los diversos acontecimientos ocurridos; así se significa un concepto de pueblo originario ausente, extinto. La ausencia de voz que se plasma de manera evidente, se naturaliza, ya que si seguimos la línea de las imágenes y textos presentados en cada introducción de unidad, se interpreta que los pueblos originarios fueron sometidos de justa manera a través de medios legítimos de poder y habilidad por parte de los europeos: ¿faltará otra perspectiva frente a tales acontecimientos? ¿Cómo ser fieles a la intención de respeto y valorización de la diversidad étnica declarada en los documentos oficiales? Esta representación que aparece de manera regular a lo largo del texto escolar es la consecuencia de una mirada única, en donde la diversidad se destaca por su ausencia.

Otro aspecto relevante consiste en los recursos semióticos que se utilizan para potenciar los significados. Del análisis multimodal se puede observar que en el caso de los europeos abundan imágenes naturalísticas, en donde se representan como realidad acontecimientos que son relativos, sumado a la frecuente cita de autor que se le agrega a cada imagen europea para aumentar veracidad. En el caso de los pueblos originarios, la mayoría de las imágenes corresponden a caricaturas o dibujos simbólicos, imaginarios, presentados sin rigor histórico, sin usarlos como fuentes secundarias no citar autoría de la representación visual. Estos recursos potencian el sentido que se configura a lo largo del texto: una voz y una versión de la historia que es la que se debe escuchar, la voz europea y su versión de los hechos.

Así, es posible apreciar una voz única que se sostiene a lo largo del texto escolar, la de los "conquistadores". En este sentido el lector configurará como verdadera y real la visión propuesta por el texto, en donde se valora explícitamente la perspectiva europea, lo cual violenta o conflictúa una perspectiva diferente a lo planteado formalmente. Por lo tanto, se aprecia una carencia en la valoración de la diversidad de voces, pues es siempre una la que se manifiesta, mientras las otras se expresan por su silencio.

Es necesario comprender, que la carencia de la voz de la contraparte, afecta a la totalidad de la red cultural (Lischinsky y Morales, 2008), puesto que la naturaleza diversa de las relaciones sociales es inexorable, existe lo queramos o no. Por lo cual, es esperable que en una sociedad se escuchen la mayor cantidad de voces posibles, para generar así un sentido cultural común pero narrado por los grupos particulares.

Sumado a esto, se observa que en el texto escolar no se considera al lector perteneciente a los pueblos originarios ¿Qué opinará un mapuche del como es representado en los textos escolares? Ciertamente si el niño posee una pertenencia e identidad definida 
con respecto a su cultura, él mismo otorgará una segunda voz frente al texto, verá la disparidad frente a como se presenta la información, y, en definitiva, chocará su mirada frente al de los textos escolares, siendo la suya (evidentemente) la falsa, la sin fundamento. Este choque puede producir un silencio en los lectores que comprenden el mundo de una manera diferente a la representada oficialmente, lo que Rockwell (2006) denomina resistencia en el aula, una resistencia a cambiar su voz, su mirada. Tal vez esto pueda ser una nueva medida del nivel de diversidad que poseemos frente a los recursos pedagógicos que se utilizan, el nivel de satisfacción, identificación y pertenencia que pueden tener los grupos minoritarios frente al texto escolar.

Finalmente, ¿Cómo se plasma esta información a aspectos concretos del docente de aula? Desde el Estado de Chile se potencia una política de la diversidad étnica, social, física, cognitiva; mas en los textos escolares esta visión no se refleja de forma plena, si bien en ocasiones aparece la imagen o la temática de los pueblos originarios, siempre aparece desde la perspectiva de otro. ¿Qué rol juega el docente? El texto escolar ha de ser siempre mediado por el profesor, puesto que las imágenes por sí solas se presentan fuertemente sesgadas y muchas veces son técnicamente imprecisas. Con respecto a esto es necesario retomar a Martins (2006), quien expresa la legitimación que se le da al texto escolar con respecto a su campo de conocimiento, en donde aquello que aparece como verdadero en el texto no deja espacios para reflexiones o cuestionamientos. La reflexión queda como responsabilidad de las mediaciones docentes, en donde debiera él o ella otorgar la voz que no aparece en los textos, en este caso a la de los pueblos originarios. Sin embargo, la construcción semiótica que se entrega en los textos, no solo configura los conceptos a través de lenguaje sino que de manera importante a través de las imágenes. Esto nos otorga nuevas preguntas y proyecciones de investigación por ejemplo ¿está preparado el docente para trabajar con textos multimodales? ¿Cómo interpreta las imágenes el docente que media el texto? Desde Martins (2006) la metodología de enseñanza en el uso de este recurso, la didáctica del docente y las estrategias utilizadas por el estudiante han de ser distintas y más complejas a la hora de enfrentarse a este tipo de textos, por lo cual cabe la reflexión si acaso es necesario preparar desde la formación inicial a los docentes para trabajar de forma multimodal y desarrollar estrategias para este respecto.

Siguiendo esta perspectiva, es necesario tener en cuenta que la configuración del concepto referido a una etnia o cultura determinada es compleja, puesto que es otro el que relata la visión de estas, el cual posee una carga histórica y de poder, además de intereses con respecto a la etnia o cultura que configura como concepto. En este sentido, el Estado de Chile se hace cargo a través de las ley indígena y la educación en la diversidad de este respecto, apela a valorar la diversidad étnica y de cada persona humana. No obstante, queda mucho camino por recorrer en la valoración de la diversidad, a través de los medios y formas en que se realiza esta acción. Por el momento nos queda como docentes, estar atentos a la mediación que podemos realizar en post de darle voz a las minorías a través del recurso de los textos escolares y otros que son distribuidos a las escuelas que reciben subvención. El desafío parece ser generar los espacios para que la voces múltiples de todos los participantes de la sociedad chilena se expresen en las aulas, a través de los textos escolares y los diversos recursos utilizados en esta poderosa herramienta llamada educación. 


\section{REFERENCIAS BIBLIOGRÁFICAS}

\section{Fuente primaria}

Ramírez, F. y Silva, V. (2009). Historia, geografía y ciencias sociales. Quinto año básico. Santiago de Chile: MN editorial Ltda.

\section{Fuentes secundarias}

Altaminaro, P., Godoy, G., Mayorga, V. y Soto, G. La configuración del concepto de pueblos originarios en los textos escolares de Historia entregados por el MINEDUC, de 4rto básico a 2 do medio, desde una perspectiva multimodal. Valparaíso, Chile: Pontificia Universidad Católica de Valparaíso.

Alzate, M. V., Gómez, M. Á., y Romero, F. (1999). La iconografía en los textos escolares de ciencias sociales. Ciencias Humanas, 22.

Arnaiz, P. (2009). Atención a la Diversidad Programación Curricular. Costa Rica: EUNED.

Barletta, N. y Mizuno, J. (2011). Una propuesta metodológica para la meta reconstrucción histórica, en Oteiza, T. y Pinto, D., En (re)construcción: discurso, identidad y nación en los manuales escolares de historia y de ciencias sociales (pp. 89-128). Santiago: Cuarto Propio:

Calzadilla, P. y Salazar, Z. (2000). El negro: la presencia ausente. Negro y esclavitud, imágenes en los textos escolares. Revista de teoría y didáctica de las ciencias sociales, $n$. 5, 99-125.

Eggins, S. y Martin, J. (2003). El contexto como género: una perspectiva lingüística funciona. Revista Signos, vol. 36, n. 54, 185-205.

Geertz, C. (2003). La interpretación de las culturas. Barcelona: Gedisa.

Halliday, M. y Martin, J. (1997). Language, context and text: aspects of language in a social semiotic perspective. Oxford: Oxford University Press.

Halliday, M. (1978). Language as a Social Semiotic. The Social Interpretation of Language and Meaning. London: Edward Arnold.

Ilich, I. (2011). La sociedad desescolarizada. Temuco: Editorial Sin Nombre.

Jomtiem. (1990). Declaración Mundial de la Educación para todos. La satisfacción de las necesidades básicas del aprendizaje. UNESCO.

Kress, G. y T. van Leeuwen (1996). Reading Images. The Grammar of Visual Design. London: Routledge.

Kress, G. (1996). Representational resources and the production of subjectivity: Questions for the theoretical development of Critical Discourse Analysis in a multicultural society. En Carmen Rosa Caldas- Coulthard y Malcolm Coulthard (Eds.), Texts and Practices. Readings in Critical Discourse Analysis. London: Routledge.

Kress, G. (2010). Multimodality: A social semiotic approach to contemporary communication. London: Routledge.

Latour, B. (2008). Reensamblar lo social: una introducción a la teoría del actor-red. Buenos Aires: Ediciones Manantial.

Lischinsky, A. y Morales, O. (2008). Discriminación a través de las ilustraciones de libros de texto de Educación Secundaria Obligatoria en España. Discurso \& Sociedad, Vol. 2, n. 1, 115-152.

Martins, I. (2006). Analisando livros didáticos na perspectiva dos Estudos do Discurso: compartilhando reflexões e sugerindo uma agenda para a pesquisa. Pro-Posições, vol. 17, n. 1, 49.

MINEDUC. (2004). Nuevas perspectivas y visión de la Educación Especial. Informe de la Comisión de Expertos. Santiago de Chile: MINEDUC.

Moss, G. (2010). Un modelo funcional del lenguaje. En Chamorro, D. y Barletta, N. (Eds.), Texto y aprendizaje: enredos y desenredos (pp.15- 26). Barranquilla: Editorial Universidad del Norte. 
Oteiza, T. (2006). El discurso pedagógico de la historia: un análisis lingüistico sobre la construcción ideológica de la historia de Chile (1980-2001). Chile: Frasis.

Painter, C., Martin, J. R., y Unsworth, L. (2012). Reading Visual Narratives: Image Analysis in Children's Picture Books. London: Equinox.

Petrus, A. (1997). Pedagogía social. Madrid: Ariel.

Ramírez, T. (2002). El blanco, el mestizo, el negro y el indio en los textos escolares de educación básica en Venezuela. Investigación y Postgrado, vol. 1, n. 17, 47-82.

Rockwell, E. (2006). Resistencia en el aula: entre el fracaso y la indignación. En Educ. Rev., $n$. $44,13-40$.

Rüsen, J. (1992). El desarrollo de la competencia narrativa en el aprendizaje histórico. Una hipótesis ontogenética relativa a la conciencia moral. Buenos Aires: FLACSO.

Van Dijk,T. (2003). Dominación étnica y racismo discursivo en España y América Latina. Barcelona: Gedisa.

Vigotsky, L. (1998). Lenguaje y pensamiento. La Habana: Pueblo y educación.

Wells, G. (2001). Indagación dialógica. Buenos Aires: Paidos.

Wilhelm, R. (1990). Análisis de contenido de libros de estudios sociales en las escuelas primarias de Guatemala. Ciudad de Guatemala: Litografía. 